\title{
Effect of New Zealand Sujon blackcurrant on resting cardiovascular function in triathletes
}

\author{
Mark ET Willems*', Stephen D Myers, Matthew D Cook, Mandy L Gault \\ From The Eleventh International Society of Sports Nutrition (ISSN) Conference and Expo \\ Clearwater Beach, FL, USA. 20-21 June 2014
}

\section{Background}

Blackcurrant contains anthocyanin, a component known to induce vasorelaxation and vasodilation in rat aortic rings [1]. In humans, blackcurrant intake has been reported to increase peripheral blood flow [2], with higher anthocyanin intake having beneficial effects on cardiovascular function in women [3]. However, the effect of blackcurrant intake on cardiovascular function in endurance-trained athletes is unknown. We examined the effect of 1-week Sujon blackcurrant powder supplementation on resting cardiovascular function of trained triathletes.

\section{Methods}

Thirteen healthy triathletes with $>3$ years experience $(8$ men; mean \pm SD: age: $38 \pm 8$ years, height: $174 \pm 5 \mathrm{~cm}$, body mass: $71 \pm 9 \mathrm{~kg}$, BMI: $23 \pm 2$, BF\%: $19 \pm 5 \%, \mathrm{VO}_{2} \max : 49.1$ $\pm 6.2 \mathrm{~mL} \mathrm{~kg}^{-1} \mathrm{~min}^{-1}$, maximum power: $305 \pm 68 \mathrm{~W}$ ) volunteered. Participants were tested following 7 days of Sujon blackcurrant powder (S, 6g/day) or placebo (P) intake, administered following a double-blind, crossover, randomized design with a wash-out period of 4 weeks. Cardiovascular function was recorded for $20 \mathrm{~min}$ in supine participants using a beat-to-beat blood pressure monitoring system (Portapres ${ }^{\circledR}$ Model 2, Finapres Medical Systems BV, Amsterdam, The Netherlands). Cardiovascular measures were averaged over 10 consecutive beats, with the lowest systolic blood pressure (BP) and associated measures analysed. Paired twotailed $t$-tests were used for analysis with significance accepted at $\mathrm{p} \leq .05$. Consent to publish the results was obtained from all participants.

\footnotetext{
* Correspondence: M.Willems@chi.ac.uk

Department of Sport and Exercise Sciences, University of Chichester, Chichester, United Kingdom
}

\section{Results}

There were no differences in systolic BP (P: $121 \pm 23$, S: 120 $\pm 23 \mathrm{mmHg}, \mathrm{p}=.92$ ), diastolic BP (P: $69 \pm 16$, S: $63 \pm 14$ $\mathrm{mmHg}, \mathrm{p}=.12)$, mean arterial BP (P: $86 \pm 18, \mathrm{~S}: 82 \pm 18$ $\mathrm{mmHg}, \mathrm{p}=.33)$, and heart rate (P: $58 \pm 9$, S: $59 \pm 10$ beats $\left.\min ^{-1}, \mathrm{p}=.95\right)$. Stroke volume (P: $82 \pm 23, \mathrm{~S}: 99 \pm 25 \mathrm{~mL}$, $\mathrm{p}<.01)$ and cardiac output (P: 4.8 $\pm 1.6, \mathrm{~S}: 5.8 \pm 1.7 \mathrm{~L}, \mathrm{p}<.05)$ were increased by $25 \%$ and $26 \%$, respectively. There was a 16\% lower total peripheral resistance (P: 20.2 \pm 8.9 , S: 15.2 $\pm 5.3 \mathrm{mmHg} \mathrm{L}^{-1} \mathrm{~min}^{-1}, \mathrm{p}=.05$ ). The changes in resting cardiovascular function were observed in 10 participants.

\section{Conclusions}

Resting cardiovascular function of trained endurance athletes responds positively to 1 -week intake of New Zealand Sujon blackcurrant powder. Intake of New Zealand Sujon blackcurrant powder is associated with 1) an increase in stroke volume and cardiac output, and 2) a decrease in total peripheral resistance. For resting skeletal muscles, these observations may influence the delivery of nutrients and clearance of metabolites. The effect on New Zealand Sujon blackcurrant on resting cardiovascular function may support the recovery of endurance athletes.

\section{Acknowledgement}

Funding for this study and conference attendance was provided by the University of Chichester, Health Currancy Ltd (UK) and Gibb Holdings (Nelson) Ltd (NZ).

Published: 1 December 2014

\section{References} endothelial cell membrane transport in red wine polyphenols-induced coronary vasorelaxation: involvement of bilitranslocase. Food Funct 2013, 4(10):1452-6.

2. Matsumoto H, Kamm KE, Stull JT, Azuma H: Delphinidin-3-rutinoside relaxes the bovine ciliary smooth muscle through activation of ETB receptor and NO/cGMP pathway. Exp Eye Res 2005, 80(3):313-22. 
3. Jennings A, Welch AA, Fairweather-Tait SJ, et al: Higher anthocyanin intake is associated with lower arterial stiffness and central blood pressure in women. Am J Clin Nutr 2012, 96(4):781-8.

doi:10.1186/1550-2783-11-S1-P3

Cite this article as: Willems et al:: Effect of New Zealand Sujon

blackcurrant on resting cardiovascular function in triathletes. Journal of

the International Society of Sports Nutrition 2014 11(Suppl 1):P3.

Submit your next manuscript to BioMed Central and take full advantage of:

- Convenient online submission

- Thorough peer review

- No space constraints or color figure charges

- Immediate publication on acceptance

- Inclusion in PubMed, CAS, Scopus and Google Scholar

- Research which is freely available for redistribution

Submit your manuscript at www.biomedcentral.com/submit 